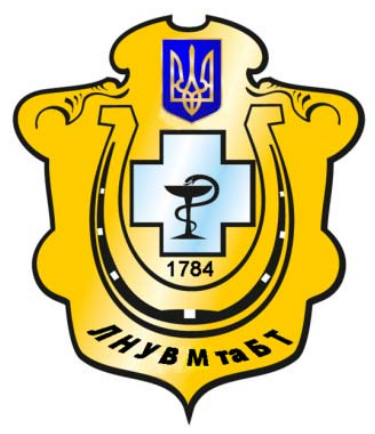

Науковий вісник Львівського національного університету ветеринарної медицини та біотехнологій імені С.3. Гжицького

Scientific Messenger of Lviv National University of Veterinary Medicine and Biotechnologies named after S.Z. Gzhytskyj

doi:10.15421/nvlvet7035

ISSN 2413-5550 print

ISSN 2518-1327 online

$\underline{\text { http://nvlvet.com.ua/ }}$

УДК $664-035: 06.15$

\title{
Нормативно-правові акти щодо безпечності і якості харчових продуктів
}

\author{
H.I. Кос'янчук \\ ninaiva2@mail.ru \\ Національний університет біоресурсів і природокористування Украӥни, \\ вул. Героїв Оборони, 15, м. Київ, 03041, Украӥна
}

\begin{abstract}
Проведено аналіз законодавчих актів щодобезпечності і якості харчових продуктів.За умов вступу будь-якої країни до світових структур обов'язкова умова - проведення атестачії і акредитачії робочих місць, обладнання, персоналу лабораторій відповідно до вимог GLP (належна лабораторна практика). Аналіз відповідної документаиії, а саме: Директиви Ради 93/99 ЕЕС від 29 жовтня 1993року, стосовно додаткових заходів для офіиійного контролю продуктів харчування, Рімення 98/179 ЕС щодо лабораторій, які проводять офіиійний контроль, вказує на необхідність їх акредитаиії у відповідності до ДСТУ ISO/IEC 17025:2006 з січня 2002 року. У відповідності з Рішенням 98/179 ЕС, для затверджених лабораторій обов'язковою є участь у міжнародно-визнаній зовнішній оціниі контролю якості і схемі акредитаиії. Крім того, затверджені лабораторії повинні підтверджувати свою компетентність у ході регулярної і успішної участі у відповідних схемах професійного тестування, визнаних або організованих національними референс-лабораторіями або референслабораторіями Спільноти. Згідно з міжнародними вимогами до харчових продуктів контролювати тільки якість продукиіі недостатньо, оскільки це не може гарантувати ї̈ повну безпечність. Необхідно впроваджувати нові системи управління безпечністю та якістю продукиії в сучасному виробничому процесі.
\end{abstract}

Ключові слова: якість, безпека, сировина, виробник, харчовий кодекс, продукти, ризик, система контролю,персонал,споживач.

\section{Нормативно-правовые акты по безопасности и качества продуктов питания}

\author{
Н.И. Косьянчук \\ ninaiva2@mail.ru \\ Национальный университет биоресурсов и природопользования Украины, \\ ул. Героев Обороны, 15, г. Киев, 03041, Украина
}

\begin{abstract}
Проведен анализ законодательных актов по безопасности и качества пищевых продуктов. В условиях вступления любой страны в мировые структуры обязательное условие - проведение аттестации и аккредитаџии рабочих мест, оборудования, персонала лабораторий в соответствии с требованиями GLP (надлежащая лабораторная практика).

Анализ соответствующей документации, а именно: Директивы 93/99 ЕЕС от 29 октября 1993 года, относительно дополнительных мероприятий для официального контроля продуктов питания, Решение 98/179 ЕС по лабораторий, проводящих официальный контроль, указывает на необходимость их аккредитаиии в соответствии с ДСТУ ISO / IEC 17025: 2006 с января 2002 года. В соответствии с Решением 98/179 ЕС, для утвержденных лабораторий обязательным является участие в международно-признанной внешней оиенке контроля качества и схеме аккредитации. Кроме того, утверждены лаборатории должны подтверждать свою компетентность в ходе регулярной и успешного участия в соответствуюших схемах профессионального тестирования, признанных или организованных национальными референс-лабораториями или референс-лабораториями Сообщества.

Согласно международным требованиям к пищевым продуктам контролировать только качество продукиии недостаточно, поскольку это не может гарантировать ее полную безопасность. Необходимо внедрять новые системы управления безопасностью и качеством продукиии в современном производственном прочессе.
\end{abstract}

Citation:

Kos'yanchuk, N. (2016). Legislative acts on safety and quality food. Scientific Messenger LNUVMBT named after S.Z. Gzhytskyj, 18, 3(70), 150-152. 
Ключевые слова: качество, безопасность, сырье, производитель, пищевой кодекс, продукты, риск, система контроля, персонал, потребитель.

\title{
Legislative acts on safety and quality food
}

\author{
N. Kos'yanchuk \\ ninaiva2@mail.ru \\ National university of life and environmental sciences of Ukraine, \\ Heroyiv Oborony Str., 11, Kyiv, 03041, Ukraine
}

\begin{abstract}
The analysis of legislation on the safety and quality of food. Under the conditions of accession of any country to international structures prerequisite - the certification and accreditation of workplaces, equipment and laboratory staff in accordance with the requirements of GLP (Good laboratory practice).

Analysis of relevant documentation, namely Council Directive 93/99 EEC of 29 October 1993 on additional measures for the official control of foodstuffs, Decision 98/179 EC on laboratories conducting official control, indicates the need for accreditation in accordance with ISO ISO / IEC 17025: 2006 since January 2002. In accordance with Decision 98/179 EC for approved laboratories is mandatory participation in an internationally recognized external quality control assessment and accreditation scheme. Moreover, approved laboratories must prove their competence in the course of regular and successful participation in relevant professional testing schemes recognized or organized by the national reference laboratory or the Community reference laboratory.

According to international requirements for food product quality control only insufficient, since it can not guarantee its complete safety. It is necessary to introduce new safety management system and product quality in the modern production process.
\end{abstract}

Key words: quality, safety, raw material, manufacturer, food code, products, riskcontrolsystem, thestaff, theconsumer

\section{Вступ}

Впродовж останніх років надзвичайно гостро постало питання безпечності, якості та конкурентоспроможності продукції вітчизняного виробництва. Нині в Україні виробляється і надходить для реалізації значна кількість продуктів харчування, які можуть, за певних умов становити ризик для споживача (Prudnikov, 2001; Petrychenko, 2008).

Проблема приховується не лише у застарілих виробничих потужностях, неналежній нормативній базі, тотальній фальсифікації, нестачі неякісної сировини, але й у способі виробництва цієї сировини. Для гарантування якості і безпечності під час виробництва харчових продуктів виробники повинні застосовувати систему контролю якості сировини на всіх ланках виробництва харчового ланцюга, починаючи з контролювання внесення мінеральних добрив і засобів захисту рослин на пасовищах, джерел забору води, стану здоров'я і умов утримання тварин і закінчуючи одержанням, зберіганням і транспортуванням готової продукції.

Мета досліджень. Провести аналіз сучасних нормативних документів, які надають рекомендації щодо отримання безпечної і якісної продукції.

\section{Результати та їх обговорення}

У лютому 2002 року ухвалено «Постанову СС № $178 / 2002$ року про визначення загальних принципів $i$ вимог харчового кодексу, створення Європейського органу для безпечності продуктів харчування і встановлення заходів для безпеки харчових продуктів» (Postanovu JeS №178/2002), що заклала підвалини нового законодавства 3 безпеки харчових продуктів. Вона визначає п'ять основних загальних принципів:

- твердження про нерозривність усіх ланок харчового ланцюга;

- аналіз ризиків безпеки харчових продуктів;
- відповідальність операторів у цій сфері;

- можливість контролювати продукт на кожній стадії харчового ланцюжка;

- право громадян на точну й достовірну інформацію.

Цією ж постановою засновано Свропейське агентство 3 безпеки харчових продуктів. Його основними завданнями $\epsilon$ надання незалежних наукових висновків стосовно безпеки харчових продуктів, збір та аналіз даних про будь-які потенційні або наявні ризики та підтримка постійного діалогу з громадськістю.

Продукція, яка може нести небезпеку для здоров'я і життя людей, тварин, рослин, майна громадян, довкілля згідно Закону України «Про підтвердження відповідальності» знаходиться у законодавчо регульованій сфері. На таку продукцію у законодавчому порядку розроблені максимально допустимі рівні показників безпеки. Процедуру підтвердження відповідності здійснює третя, незалежна від виробника чи споживача сторона, якою є уповноважені органи сертифікації продукції, підпорядковані Центральному органу виконавчої влади у сфері підтвердження відповідності. Процедура підтвердження відповідності у законодавчо регульованій сфері є обов'язковою для виробника, постачальника чи уповноваженого органу з сертифікації (Gumenjuk, 2011).

В кінці 2005 року набув чинності Закон України «Про стандарти, технічні регламенти та процедури оцінки відповідності». Згідно цього закону на продукцію, яка може нести небезпеку для життя і здоров'я людей, тварин та довкілля розробляються технічні регламенти (ТР). Метою розроблення і застосування ТР є захист і здоров'я людей, тварин та запобігання не належній виробничій практиці.

За умов вступу будь-якої країни до світових структур обов'язкова умова - проведення атестації і акредитації робочих місць, обладнання, персоналу лабораторій відповідно до вимог GLP (належна лабораторна практика) (Bilous et al., 2011). 
Аналіз відповідної документації, а саме: Директиви Ради 93/99 ЕЕС від 29 жовтня 1993року, стосовно додаткових заходів для офіційного контролю продуктів харчування, Рішення 98/ 179 ЕС щодо лабораторій, які проводять офіційний контроль, вказує на необхідність їх акредитації у відповідності до ДСТУ ISO/IEC 17025: 2006 з січня 2002 року. У відповідності з Рішенням 98/179 ЕС, для затверджених лабораторій обов'язковою $є$ участь у міжнародно-визнаній зовнішній оцінці контролю якості і схемі акредитації. Крім того, затверджені лабораторії повинні підтверджувати свою компетентність у ході регулярної і успішної участі у відповідних схемах професійного тестування, визнаних або організованих національними референс-лабораторіями або референслабораторіями Спільноти.

Особливе місце відводиться методикам, які після апробації повинні бути валідовані відповідно до стандарту ДСТУ ISO/IEC 17025: 2006 і «Свропейській інструкції щодо застосування аналітичних методів та інтерпретації результатів ЕС 657/2002». Ця процедура проводиться після затвердження або при проведенні внутрішньолабораторного контролю.

Міжнародна організація стандартизації розробила ISO 22000:2005«Системи управління безпечністю харчових продуктів. Вимоги до будь-яких організацій харчового ланцюга»,який з квітня 2007 р. чинний в Україні, як ДСТУ ISO 22000:2007, зазначає, що оскільки небезпечний чинник у харчових продуктах може 3'явитися на будь-якій ланці харчового ланцюга.

За виробництво неякісної продукції вітчизняні законодавчі органи неодноразово домагались ввести карну відповідальність і тільки у 2013 році був розглянутий на Верховній Раді проект Закону «Про відповідальність за виробництво неякісної продукції». Він передбачає підвищити відповідальність виробників за якість продукції внесенням відповідних змін у 13 законодавчих актів України: закони «Про безпечність і якість харчових продуктів», «Про вилучення з обігу, переробку, утилізацію, знищення або подальше використання неякісної та небезпечної продукції», «Про ветеринарну медицину» тощо (Bukalova, 2005).

Закон України «Про основні принципи та вимоги до безпечності та якості харчових продуктів» 20 вересня 2016 року, вступив у дію, згідно якого відповідальність повністю за безпечність та якість харчових продуктів покладено на виробника. Отже, необхідно зазначити, що однією із причин виробництва та реалізації недоброякісних харчових виробів $є$ недосконалість ветеринарно-санітарного контролю в умовах виробництва та реалізації продукції.

За даними комітету Охорони прав споживачів в Україні близько 80\% харчових продуктів фальсифіковано. Найчастішою підробкою $є$ заміна харчового продукту замінниками іншого виду і нижчої якості. Така фальсифікація частіше відбувається під час виробництва ковбас (Kravciv and Koval', 2003).

Система контролю якості та безпечності продукції тваринництва, що добре була налагоджена i, практично, діє у нашій країні - в сучасних умовах малоефективна і не може дати відповіді на вже виниклі і пос- тійно виникаючі проблеми у галузі безпеки продовольства, тому що в ній майже не враховується профілактичний аспект (Gerasymenko, 2000; Drachova, 2007; Ehlakova, 2008).

\section{Висновки}

Згідно 3 міжнародними вимогами до харчових продуктів контролювати тільки якість продукції недостатньо, оскільки це не може гарантувати іiі повну безпечність. Необхідно впроваджувати нові системи управління безпечністю та якістю продукції в сучасному виробничому процесі.

\section{Бібліографічні посилання}

Petrychenko, O.A. (2008). Tendencija rozvytku efektyvnosti galuzi skotarstva. Zb. nauk. prac' VDAU. 39, 45-55 (in Ukrainian).

Prudnikov, V. (2001). M'jasna syrovyna dlja vyrobnyctva produktiv dytjachogo harchuvannja. Tvarynnyctvo Ukrai'ny. 3, 5-6 (in Ukrainian).

Postanovu JeS №178/2002 roku «Pro vyznachennja zagal'nyh pryncypiv i vymog harchovogo kodeksu, stvorennja Jevropejs'kogo organu dlja bezpechnosti produktiv harchuvannja i vstanovlennja procedur u galuzi bezpeky harchovyh produktiv» vid 28 sichnja 2002 roku (in Ukrainian).

Gumenjuk, G.D. (2011). Derzhavne reguljuvannja jakosti i bezpechnosti sil's'kogospodars'koi' ta harchovoi' produkcii'. Mizhnarodna naukovo-praktychna konferencija molodyh vchenyh, aspirantiv i studentiv K.: NUBiP Ukrai'ny. Vyd-vo TOV «Agrar Media Grup». 15-16 (in Ukrainian).

Bilous, A.O., Baranov, Ju.S., Novozhylova, Je.V. (2011). Validovani metodyky . - neobhidna umova nadijnosti systemy upravlinnja bezpechnosti produkcii'. Mizhnarodna naukovo-praktychna konferencija molodyh vchenyh, aspirantiv i studentiv K.: NUBiP Ukrai'ny. Vyd-vo TOV «Agrar Media Grup», 20 (in Ukrainian).

Bukalova, N.V. (2005). Dejaki aspekty ekologichnoi' chystoty vyrobnyctva m'jasnyh produktiv ta minimizacija v nyh shkidlyvyh dlja zdorov'ja ljudyny rechovyn. Ekotrofologija. Suchasni problemy: Materialy 1 mizhnarodnoi' konferencii'. Bila Cerkva. 25 travnja. 133-136 (in Ukrainian).

Kravciv, R.J., Koval', G.M. (2003). Jalovychyna - cinnyj produkt harchuvannja. Naukovyj visnyk L'vivs'koi' nacional'noi' akademii' veterynarnoi' medycyny im. S. Z. Gzhyc'kogo. L'viv. 5, 3, 3, 151-155 (in Ukrainian).

Ehlakova, N.V. (2008). Kachestvo i bezopasnost' mjasoproduktov. Jeffektivnoe pticevodstvo. 8, 28-31 (in Ukrainian).

Drachova, L. (2007). Jakist' i bezpeka harchovyh produktiv. Harchova i pererobna promyslovist'. 1, 1518 (in Ukrainian).

Gerasymenko, L.P. (2000). Mikrobiologichnyj kontrol' v harchovij promyslovosti. Harchova promyslovist'. 4, 19 (in Ukrainian).

Стаття надійшла до редакиії 3.10.2016 